\title{
GRM4 Gene
}

National Cancer Institute

\section{Source}

National Cancer Institute. GRM4 Gene. NCI Thesaurus. Code C114532.

This gene plays a role in neurotransmitter signaling. 